\title{
Regulation of amino acid transport system $L$ by amino acid availahility in CHO-K1 cells. A special role for leucine
}

\author{
Alfredo Moreno *.**, Carmen D. Lobatón * and Dale L. Oxender \\ Department of Biological Chemistry, The University of Michigan, Ann Arbor, MI 48109 (U.S.A.)
}

(Received June 10th, 1985)

Key words: Transport regulation; Amino acid transport; Transport system L; Leucine starvation; (CHO-Kl cell)

Starvation of CHO-K1 cells for leucine leads to a 3-4-fold increase in transport system $\mathrm{L}$ activity, without modification of transport through systems A and ASC. The concentration of leucine must be below $10 \mu \mathrm{M}$ before the enhancement of transport can be clearly seen. To achieve low concentrations of leucine such as 10 $\mu \mathrm{M}$, extensive dialysis of fetal calf serum was required. The enhancement of transport was completed after 12-24 h of starvation and was fully reversed within $1 \mathrm{~h}$ of re-feeding with leucine. Starvation for isoleucine, valine or phenylalanine also produced an increase in system $L$ transport activity, but the effect was only one half of that seen following leucine starvation.

Animal cells can modify their amino acid transport activities in response to changes in conditions of growth and nutrition [1-3]. Most of these regulatory modifications of transport have been ascribed to the $\mathrm{Na}^{+}$-dependent transport system $A$, while the activity of the $\mathrm{Na}^{+}$-independent transport system $L$ was usually unaffected [1-7]. System $L$ regulation has been reported, however, in the Chinese hamster ovary tsH1 cell line, a temperature-sensitive leucyl-tRNA synthetase mutant. Incubation of these cells at $38^{\circ} \mathrm{C}$, a temperature at which the leucyl-tRNA synthetase is partially inactivated, resulted in leucine-limited growth and a 2-3-fold increase in the activity of transport system L. An increase in transport system $\mathrm{L}$ activity was also found in the parental CHO-S cell line, which has normal leucyl-tRNA synthetase activity, incubated at very low leucine concentrations, although the effect was smaller $[8,9]$. In this paper we have studied regulation of

\footnotetext{
* Present address: Departamento de Fisiologia y Bioquimica, Facultad de Medicina, 47005 Valladolid, Spain.

** To whom correspondence should be addressed.
}

system $\mathrm{L}$ activity in the CHO-K1 cell line, which also has normal leucyl-tRNA synthetase activity.

The CHO-K1 cell line was obtained from Dr. L.H. Thompson, Lawrence Livermore Laboratory, CA. The procedures for culture and transport assays were essentially as described previously [10]. Other technical details are given in the legends to the figures and tables.

We first examined the growth of $\mathrm{CHO}-\mathrm{K} 1$ cells at $37^{\circ} \mathrm{C}$ in leucine-free Eagle's minimal essential medium (K.C. Biological) containing Earle's salts, non-essential amino acids and $2.2 \mathrm{~g} / \mathrm{I}$ sodium bicarbonate (leucine-free medium) and supplemented with $5 \%(\mathrm{v} / \mathrm{v})$ commercial dialyzed fetal calf serum (Gibco). As shown in Fig. 1 the cells were able to grow quite satisfactorily in this medium. On the contrary, if the commercial serum was extensively dialyzed prior to use ( 6 days against 20 volumes of Earle's salts with daily change of dialysis medium), the cells were unable to grow in leucine-free medium. The addition of as little as 1 $\mu \mathrm{M}$ leucine to this medium allowed significant growth. As the leucine concentration was increased the growth rate increased also, reaching a 


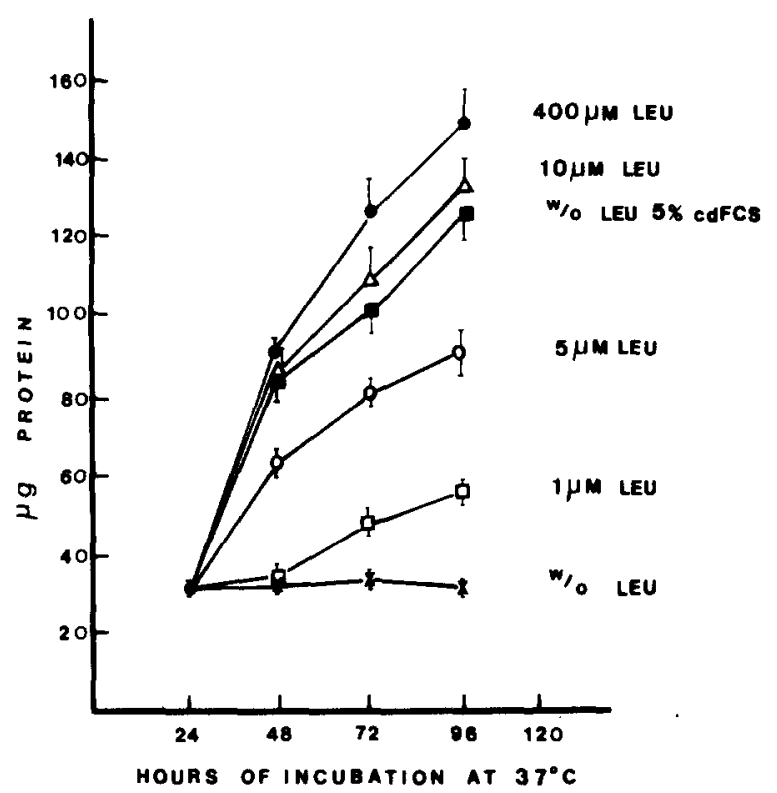

Fig. 1. Growth of CHO-K1 cells in media containing decreasing leucine concentrations. CHO-K1 cells were seeded in $20 \mathrm{ml}$ glass vials at $0.5 \cdot 10^{5}$ cells per vial and incubated at $37^{\circ} \mathrm{C}$ in regular medium supplemented with $5 \%$ fetal calf serum. After $24 \mathrm{~h}$ the medium was removed and the cells washed twice with $5 \mathrm{ml}$ of $\mathrm{Na}^{+}$-containing phosphate buffer. The cultures were then incubated at $37^{\circ} \mathrm{C}$ in $10 \mathrm{ml}$ of leucine-free medium supplemented with $5 \%$ extensively dialyzed fetal calf serum and with the leucine concentrations indicated. One group of cultures was incubated in leucine-free medium supplemented with $5 \%$ commercial dialyzed (cd) fetal calf serum (Gibco) (D). In cultures incubated with $1 \mu \mathrm{M}$ leucine ( $\square$ ) the medium was changed daily. Protein was measured in each group of cultures at the time indicated. Means \pm S.D., $n=4$.

constant value at $10 \mu \mathrm{M}$ (Fig. 1). These results suggest that the low concentration of leucine present in the commercial dialyzed serum was enough to support a near-normal rate of growth.

Table I shows the 1-min uptake of $\mathrm{I}_{-}-\left[{ }^{3} \mathrm{H}\right]$ leucine in sodium-free phosphate buffer by $\mathrm{CHO}-\mathrm{K} 1$ cells after incubation for $12 \mathrm{~h}$ in leucine-free medium supplemented with $5 \%$ extensively dialyzed serum, to which different concentrations of leucine were added. Leucine uptake increased markedly in cells first incubated at leucine concentrations below 10 $\mu \mathrm{M}$, this enhancement of transport being maximal (about 4-fold) when leucine was omitted from the incubation medium. When leucine-free medium was supplemented with commercial dialyzed serum (Gibco) only moderate enhancements (less than
TABLE I

EFFECT OF LEUCINE CONCENTRATION IN THE GROWTH MEDIUM ON THE UPTAKE OF LEUCINE IN CHO-K1 CELLS

Cultures of CHO-K1 cells were seeded in 24 well cultures at $1.1 \cdot 10^{5}$ cells per well, and grown for $24 \mathrm{~h}$ in Eagle's minimal essential medium containing Earle's salts, non essential amino acids, and $2.2 \mathrm{~g} / 1$ sodium bicarbonate (regular medium) supplemented with $5 \%$ fetal calf serum. The cultures were then washed twice with $2 \mathrm{ml}$ per well of $\mathrm{Na}^{+}$-containing phosphate buffer and incubated for 12 additional hours in leucine-free medium supplemented with $5 \%$ extensively dialyzed fetal calf serum and with the leucine concentrations indicated. The $1 \mathrm{~min}$ uptake of $0.2 \mathrm{mM}\left[{ }^{3} \mathrm{H}\right]$ leucine in $\mathrm{Na}^{+}$-free phosphate buffer was measured after the cells had been depleted of endogenous amino acids by 40 min of incubation in $\mathrm{Na}^{+}$-free phosphate buffer supplemented with $\mathrm{Ca}^{2+}, \mathrm{Mg}^{2+}$ and glucose as described [10]. Means \pm S.D., $n=4$.

\begin{tabular}{lc}
\hline $\begin{array}{l}\text { Leucine concn. } \\
(\mu \mathrm{M})\end{array}$ & $\begin{array}{l}\text { Leucine uptake rate } \\
\left(\mathrm{nmol} \cdot \mathrm{mg}^{-1} \cdot \mathrm{min}^{-1}\right)\end{array}$ \\
\hline 400 (Control) & $4.31 \pm 0.15$ \\
100 & $5.37 \pm 0.14$ \\
50 & $6.38 \pm 0.29$ \\
25 & $6.44 \pm 0.25$ \\
10 & $10.55 \pm 0.57$ \\
5 & $14.71 \pm 0.40$ \\
None & $18.25 \pm 0.42$ \\
\hline
\end{tabular}

2-fold) of leucine transport were observed, the effect being variable and dependent on the particular batch of serum (data not shown).

Fig. 2 shows the time-course of the leucine transport enhancement following incubation at $37^{\circ} \mathrm{C}$ in leucine-free medium. Leucine transport was doubled after $6 \mathrm{~h}$ of incubation and reached a maximum of 3-4-fold over the control value after 12-24 h of incubation. Starvation for other single amino acids which are also substrates for system $\mathrm{L}$ such as isoleucine, valine, or phenylalanine produced an increase in leucine uptake which was only one half of that following leucine starvation (Fig. 2). The starvation-dependent leucine transport enhancement was quickly reversed (within 1 h) by the addition of the missing amino acid to the medium. As shown in the right part of Fig. 2, some increase of transport takes place after the initial reversion and then the transport gradually returns to control values. The uptake of other system L substrates (isoleucine, valine and phenylalanine) was in all the cases modified similarly to 


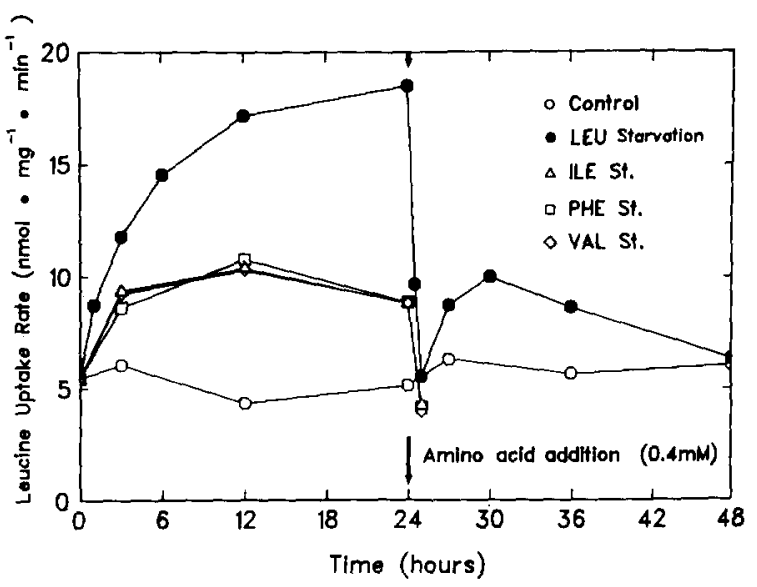

Fig. 2. Time-course of leucine transport enhancement in CHO$\mathrm{K} 1$ cells following single amino acid starvation. Cultures of CHO-K1 cells were seeded in 24-well culture dishes at $1.3 \cdot 10^{5}$ cells per well in regular medium supplemented with $5 \%$ fetal calf serum and grown for $24 \mathrm{~h}$ at $37^{\circ} \mathrm{C}$. The cells were washed twice with $2 \mathrm{ml}$ per well of $\mathrm{Na}^{+}$-containing phosphate buffer and then (zero-time) incubated in modified media lacking a single system $L$ amino acid. Control cultures were incubated in regular medium. In all the cases the media were supplemented with $5 \%$ extensively dialyzed fetal calf serum. After $24 \mathrm{~h}$ of incubation at $37^{\circ} \mathrm{C}$ the missing amino acid in each group of cultures was added at a final concentration of $0.4 \mathrm{mM}$. At the times indicated the cells were depleted of endogenous amino acids by $40 \mathrm{~min}$ incubation in $\mathrm{Na}^{+}$-free phosphate buffer supplemented with $\mathrm{Ca}^{2+}, \mathrm{Mg}^{2+}$ and glucose at $37^{\circ} \mathrm{C}$ and the 1-min uptake of $0.2 \mathrm{mM} \mathrm{L-}\left[{ }^{3} \mathrm{H}\right] l$ leucine in $\mathrm{Na}^{+}$-free buffer was measured in each group of cultures [10]. Each data point is the mean of four determinations.

leucine uptake after single amino acid starvation and the changes of transport followed the same time-course and reversion patterns as those shown for leucine in Fig. 2 (Data not shown).

The effects of leucine starvation on the activity of transport systems A, ASC and L were compared in the experiments summarized in Table II. It can be seen that leucine starvation decreases very slightly the transport activity of system $A$ and increases that of systems ASC and L. Although the effects on all the three systems were statistically significant when analysed by Student's $t$-test $(p<$ 0.05 for system A, and $p<0.001$ for systems ASC and L), the percent enhancement of system $L$ activity $(333 \%)$ was about 10 -fold higher than that observed for system ASC (37\%).

Our results demonstrate that system $L$ activity is subjected to regulation in CHO-K1 cells by the
TABLE II

\section{SPECIFICITY OF TRANSPORT ENHANCEMENT IN CHO-K1 CELLS FOLLOWING LEUCINE STARVATION}

Cultures of CHO-K1 cells were seeded in 24-well culture dishes at $1.1 \cdot 10^{5}$ cells per well and grown for $20 \mathrm{~h}$ in regular medium supplemented with $5 \%$ fetal calf serum. The cells were then washed twice with $\mathrm{Na}^{+}$-containing buffer. One half of the cultures were incubated for 24 additional hours in leucine-free medium supplemented with $5 \%$ extensively dialyzed fetal calf serum. The other half of the cultures were incubated in regular medium supplemented with $5 \%$ fetal calf serum for the same period. Systems A, ASC and L were operationally defined as follows: system $A$, the portion of the $\mathrm{Na}^{+}$-dependent uptake of $0.2 \mathrm{mM}$ 2-aminoisobutyrate (AIB) inhibitable by $25 \mathrm{mM} \mathrm{2-}$ methylaminoisobutyrate (MeAIB); system ASC, the portion of the $\mathrm{Na}^{+}$-dependent uptake of $0.2 \mathrm{mM} L$-alanine non-inhibitable by $25 \mathrm{mM}$ MeAIB; system $\mathrm{L}$, the portion of $\mathrm{Na}^{+}$-independent uptake of $0.2 \mathrm{mM}$ L-leucine inhibitable by $10 \mathrm{mM} \mathrm{2-}$ aminobicyclo[2,2,1]heptane-2-carboxylic acid (BCH). Transport assays were carried out as described [10]. Means \pm S.D., $n=4$.

\begin{tabular}{llll}
\hline $\begin{array}{l}\text { Growth } \\
\text { conditions }\end{array}$ & \multicolumn{3}{l}{ Uptake rates $\left(\mathrm{nmol} \cdot \mathrm{mg}^{-1} \cdot \mathrm{min}^{-1}\right)$} \\
\cline { 2 - 4 } & $\begin{array}{l}\text { System A } \\
(0.2 \mathrm{mM} \mathrm{AIB})\end{array}$ & $\begin{array}{l}\text { System ASC } \\
(0.2 \mathrm{mM} \\
\text { alanine })\end{array}$ & $\begin{array}{l}\text { System L } \\
(0.2 \mathrm{mM} \\
\text { leucine })\end{array}$ \\
\hline $\begin{array}{l}\text { Control } \\
\begin{array}{l}\text { Leucine } \\
\text { starvation }\end{array}\end{array}$ & $2.47 \pm 0.16$ & $5.79 \pm 0.46$ & $6.12 \pm 0.48$ \\
\hline
\end{tabular}

availability of system $\mathrm{L}$ amino acids. Previous failures to show this regulation could have been due to the presence of low concentrations of amino acids in the commercial dialyzed fetal calf serum, since very low concentrations of leucine are enough to support normal growth and transport activity. Leucine seems to play a more prominent role than other system L substrates since starvation for leucine leads to a larger increase in transport than starvation for other amino acids. Alternatively, the needs of other amino acids for protein synthesis could be better covered by break down of cellular proteins or release from other endogenous pools.

It seems conceivable that the regulatory mechanism recognizes the level of aminoacylation of tRNA rather than the size of the intracellular pool of system $L$ amino acids since the leucyl-tRNA synthetase mutant shows a similar enhancement of transport at higher concentrations of leucine [8,9]. The observation that leucinol, a competitive inhibitor of leucyl-tRNA synthetase which is not a substrate for system $L$ facilitates the enhancement 
of transport system L by leucine starvation (Moreno, A. and Lobatón, C.D. unpublished data) also supports this view. Studies are in progress to elucidate the mechanism involved in this regulation.

We are grateful to professors Benito Herreros and Javier Garcia-Sancho for helpful discussions. This work was supported by U.S.A. Public Health Service Grant GM20737 from the National Institutes of Health.

\section{References}

1 Shotwell, M.A., Kilberg, M.S. and Oxender, D.L. (1983) Biochim. Biophys. Acta 737, 267-284
2 Shotwell, M.A. and Oxender, D.L. (1983) Trends Biochem. Sci. 8, 314-316

3 Guidotti, G.G., Borghetti, A.F. and Gazzola, G.C. (1978) Biochim. Biophys. Acta 515, 329-366

4 Shotwell, M.A., Jayme, D.W., Kilberg, M.S. and Oxender, D.L. (1981) J. Biol. Chem. 256, 5422-5427

5 Gazzola, G.C., Franchi-Gazzola, R., Ronchi, P. and Guidotti, G.G. (1973) Biochim. Biophys. Acta 311, 292-301

6 Heaton, J.H. and Gelehrter, T.D. (1977) J. Biol. Chem. 252 , 2900-2907

7 Kelley, D.S. and Potter, V.R. (1979) J. Biol. Chem. 254, 6691-6697

8 Moore, P.A., Jayme, D.W. and Oxender, D.L. (1977) J. Biol. Chem. 252, 7427-7430

9 Shotwell, M.A., Mattes, P.M., Jayme, D.W. and Oxender, D.L. (1982) J. Biol. Chem. 257, 2974-2980

10 Lobatón, C.D., Moreno, A. and Oxender, D.L. (1984) Mol. Cell. Biol. 4, 475-483 